\section{\& Education}

๑ SW\&E, 2019

UDC 364.45

DOI: $10.25128 / 2520-6230.19 .2 .2$

\section{Nadiia Horishna,}

Ph.D., Associate professor of Social

Pedagogy and Social Work

Department, Ternopil Volodymyr

Hnatyuk National Pedagogical

University,

Ternopil, Ukraine

nadiahorishna@yahoo.com

ORCID: 0000-0002-9724-7098 integrated social services implementation in Ukraine, Social Work and Education, Vol. 6, No. 2., pp. 133-143. DOI: $10.25128 / 2520-6230.19 .2 .2$

\title{
THE NATURE AND
} PECULIARITIES OF INTEGRATED SOCIAL SERVICES IMPLEMENTATION IN UKRAINE

\begin{abstract}
The relevance of the article is highlighted by the need to introduce integrated social services at the local level in the context of decentralization of power and amalgamation of territorial communities. The purpose of the article is to analyze the existing approaches to the integration of social services and determine the possibilities of their application in the context of decentralization of social services at the local level in Ukraine. It is established that the implementation of an integrated approach to the provision of social services at the local level requires preliminary assessment, planning, and cooperation based on setting of the common goals and objectives, clear distribution of functions, introduction of financial and/or administrative incentives for cooperation, elimination of factors that would cause competition between service providers, and development of social service providers capacity in areas of planning, evaluation and management.
\end{abstract}

Key words: integration; social services; integrated social services; social welfare; amalgamated territorial communities.
Article history:

Received: January 10, 2019

1st Revision: May 23, 2019

Accepted: June 30, 2019 


\section{Introduction}

The reform of social services system that is currently taking place in Ukraine in the context of decentralization of power and amalgamation of territorial communities encompasses the implementation of an integrated approach to their provision. Despite the fact that the Strategy for the Development of Social Services in Ukraine until 2020 envisages such an approach, its implementation is being hampered. There are several reasons for such a situation. Firstly, the newly created communities are not interested in setting up their own structures for social services provision in situation when there are similar institutions at the district and regional levels that provide similar services on a contractual basis. Secondly, the lack of understanding of the core of social services integration, its advantages and limitations, mechanisms of implementation is observed on the part of authorities of amalgamated territorial communities (ATC), social services providers of various forms of ownership, and services consumers. Thirdly, ambiguity of the very concept of services integration, the presence of different approaches and ways of its implementation should also be taken into account.

\section{Literature review}

The results of the analysis of scientific literature indicate a significant interest of foreign researchers in the integration of social services. Earlier studies demonstrate the attempts to capture the essence of this phenomenon (Wharf, 1977; Stevens \& Webster, 1978) and to develop mechanisms of its implementation into practice (Hassett \& Austin, 1997; Agranoff, 1991). More recent studies are more specific and reveal practical aspects of social services integration into areas such as health (Austin \& Prince, 2003; Fisher \& Elnitsky, 2012); and employment (Taylor, 2009; Minas, 2009; Heidenreich \& Aurich, 2013; Minas, 2014; Heidenreich \& Rice, 2016; Hollerts, 2016). There is a considerable research documenting approaches to the provision of integrated social services in European countries (Munday, 2007; Borghi \& Van Berkel, 2007; Literature review and identification of best practices, 2015; Wollmann, Koprić \& Marcou G, 2016).

The studies of Ukrainian scientists deal with the effectiveness of the current system of social services provision at the level of ATC (Slozanska, 2017), integrated social agencies (Bespalko, Zvereva, Kyianytsia \& Kuzminskiy, 2007; Svetlichnyi, 2009; Popyk, 2016), implementation of integrated social services (Ilchuk \& Ilchuk, 2018; Popovych, 2018); social workers' capacity to provide integrated services (Slozanska, 2018). Among the achievements in the implementation of integrated social services, the authors report: improvement of legal framework (Ilchuk \& Ilchuk, 2018, p.122); development of various forms of cooperation between the ATC on joint administration of social services (Popovych, 2018, p. 212); potential capacity of pre-service social workers to provide social services to various categories of clients at the ATC level (Slozanska, 2018, p. 94). Difficulties in implementation of the integrated social services are associated with lack of understanding of social services integration, its identification with other related concepts such as, social services and integrated social agencies, lack of financial resources and commitment to the very idea of services integration, poor understanding of the mechanisms of integration at the leadership level (Ilchuk \& Ilchuk, 2018, p. 122).

The purpose of the article is to analyze the existing approaches to the integration of social services and define the possibilities of their application in the context of decentralization of social services at the local level in Ukraine. The objectives of the study include: to reveal the approaches to the interpretation of "integrated social services"; to review the development of basic approaches to the integration of social services; to discuss the factors that facilitate or hinder the integration of services at the local level in Ukraine. 


\section{Research methodology}

The method of "desk research", based on the analysis of social research data, analytical reports, publications and other scientific materials through their comparison and mutual verification, was used for the purpuses of this study. The information was searched in electronic databases such as Web of Science, ResearchGate, Google Scholar, in the database "Legislation of Ukraine", on the websites of public authorities, local governments, non-governmental organizations related to integrated social services provision.

\section{Results}

The essence of integrated social services

The analysis of scientific literature demonstrated the existence of different approaches to the interpretation of "social services" in domestic and foreign scientific literature. In Ukraine, social services are understood as: (a) a complex of measures on rendering assistance in solving social problems of individuals and social groups who are in difficult life circumstances and cannot overcome them themselves (the Law of Ukraine "On social services", 2003); (b) services provided in case of insured accident, such as unemployment, retirement, professional illness, etc. as a part of obligatory state social insurance (Smith, 2014); (c) services provided by social work professionals and funded mainly at the expense of local and state budgets, grants, charitable assistance, etc. (Kuts, Krasnoperova, 2006, p. 15-16). The latter interpretation of social services best corresponds to the concept of "personal social services" - that is services provided to individuals to meet their specific needs. Typical consumers of such services are children and families with children, people with disabilities, the elderly, people with HIV / AIDS, etc. Their suppliers are state, municipal, non-governmental organizations and private businesses. The term "personal social services" is used by the Council of Europe to differentiate them from other standardized services that are provided to certain social categories on a common basis (Munday Brian, 2007, p. 10). In order to avoid disagreements in the understanding of the concepts, in this article we will use the term "social services" in this sense.

Despite the large number of studies on various aspects of social services integration, the issue of their definition was not given due consideration. The authors of the few definitions that we have been able to find focus on certain common characteristics of such services, but define them in different ways. B. Munday defines "integrative social services" as the continuous process of planning, coordinating and providing social services through cooperation, partnership and interaction of legally independent institutions and the use of methods that take into account individual needs, circumstances and opportunities (Munday, 2007, p. 10). The authors of another study believe that integration refers to a single system of planning and/or provision of services, the implementation and management of which is carried out by partner organizations that are legally independent entities. A single system of provision of a particular service may include, for example, a common mission, organizational culture, management, budget, accommodation, registry, applied at all levels of integration - team, service or organization (Thistlethwaite, 2008, p. 12).

Analyzing the interaction in the provision of social services Hassett and \& Austin (Hassett \& Austin, 1997) reveal the core of integration, contrasting it with such concepts as communication, coordination and cooperation. Communication, in their view, provides for the exchange of information, but does not involve joint activities; coordination pursues separate common goals and leads to the use of certain types of joint activities; cooperation is not possible without setting common goals as a basis for interaction. All these forms of interaction can be used for integration - the creation of a unified system of needs assessment, implementation and provision of services.

The integrated system of social services should meet the following characteristics (Hutson, 2004): single access point - it does not matter where the client first applies, he 
should have access to a wide range of services; comprehensive needs assessment, which is the basis for the development of the service delivery plan; if the client is a family, the needs of all its member as well as strengths and weaknesses of the family as a whole should be assessed; joint planning and case management with maximum involvement of the client; co-location - the possibility of obtaining all services in one place; partnership - knowledge and understanding of the full range of services provided by partner organizations, daily communication and exchange of information.

\section{Development of approaches to the integration of social services}

The idea of integration of social services appeared in the USA in the 1960's (Agranoff, 1991, p. 442), when under the legislation on poverty reduction the community action agencies were created at the community level. These organizations provided a wide range of socio-economic services to meet the needs of the population and were managed jointly by federal and local governments. Over the next decade, the integrated approach to social services provision became widespread in the areas of public policy and management, health and mental health not only in the United States but also in many European countries. The trend towards the integration of services lost its momentum in the late 1970s and early 1980s (Agranoff, R. 1991, p. 442). The renewed interest in the idea of integrating social services in recent decades has been brought about by the reforms of social welfare systems aimed at strengthening their abilities to respond to the negative effects of globalization, economic crisis and demographic changes.

One of the ways to respond to these challenges in the context of social welfare has become the paradigm shift in the provision of services: from the social treatment model towards the model of development service delivery. According to the UN definition, social welfare for development focuses on maximizing human potential, promoting self-reliance and participation in decision-making; to achieve these objectives, the importance of family - community and integrated service delivery is emphasized (Estes, 1997).

The need for integration of social services is emphasized in the Social Investment Package of European Commission - a document which defines the basic principles for reform of social policy and modernization of social welfare systems and services focused on social investment to prevent risks, respond quickly, and support people at different stages of life. The integration of social services is considered in this document as a way to overcome new types of social risks, to ensure and expand access to social services, especially for vulnerable categories of the population, to coordinate activities between different institutions and organizations (Literature review and identification of best practices, 2015, p. 5).

Fisher \& Elnitsky having summarized all known approaches, concluded that the integration of services is often carried out within the framework of three conceptual approaches based on the allocation of levels; continuity of the process; services, clients, and society (Fisher \& Elnitsky, 2012, p. 444).

In terms of levels, integration can be individual (micro level), organizational (meso level) or inter-organizational (macro level). The relevant examples are the integration of services at the individual client/case level, between several organizations working in the same field, between organizations representing different areas of activity, such as social work and health.

Integration of services at the client and/or case level and the level of management that reflect fundamentally different approaches to the provision of services, which can be symbolically described as "top-down" and "bottom-up". In the first case, integration is initiated by policy makers, in the second - by service providers or local communities.

Integration can take place vertically, ensuring systematic and close cooperation and coordination between different levels of government, or horizontally, linking services 
provided by individual actors. An example of the latter is the provision of social services on a one-stop-shop basis (Literature review and identification of best practices, 2015, p. 24).

Integration as the continuity of the process can be illustrated by the example of services for people with different types of addictions. Integrated services can be carried out, starting with short-term intervention, provision of certain types of services, case management and ending with the establishment of institutions implementing programmes aimed at behaviour change. This process covers various forms of integration, both at the client level and at the level of management (Fisher \& Elnitsky, 2012, p. 445)

Integration can take place at the service, client and community levels. In the first case, integration efforts are aimed at implementation of a certain type or a whole range of services, joint management of social projects or programs by different organizations. In the second case, the categories of clients, such as people with disabilities, the elderly and the like serve as the basis for integration. In the third case, there is some similarity with the "bottom-up" approach, but the initiative comes from the community rather than from the organization; the population is involved in determining the best option for the integration of social services and their provision.

It should be noted that this list of approaches to the integration of social services is neither complete nor mutually exclusive; for example, levels of integration may also exist in the continuum and may lead to the differentiation by client categories and types of services (Fisher \& Elnitsky, 2012, p. 444). Specific forms of integration will depend on the scope of activities, expertise, and affiliation of organization.

\section{Ukrainian realities of social services integration}

Understanding the current state of the social services system in Ukraine makes it possible to assess feasibility, challenges, and prospects for the implementation of integrated social services.

At present, we can note some positive results of social services reform which began in 2001. These may include the development of National Standards of Social Services; open access to the social services market for non-governmental organizations, private businesses and individuals; developed and implemented mechanisms for assessment of the population needs in social services (Horishna, 2019).

However, the results of literature survey and our own observations and experiences indicate that there are still many gaps and challenges in Ukrainian social welfare system. One is that the functions of social support and assistance are distributed among many institutions related to specific problems or issues, such as health, labour market, social assistance etc. In the context of decentralization of power there is a threat of even greater dispersion and fragmentation.

Currently, the main provider of social services is the public sector, which is complemented by small non-governmental organizations (NGOs); commercial structures remain underrepresented in the market of social services. In Ukraine, $85 \%$ of social services are provided by state institutions (Goremykina, 2009). The two largest providers of social services are Centers of Social Services for Families, Children and Youth (CSSFCY) which operate at the regional, district and local levels and Departments of Social Welfare and their structural units, which operate at the level of regional and district state administrations Divisions of Labor and Social Welfare. Under the auspice of the latter operate the Territorial Centers of Social Services (TCSS). Most of such institutions are situated in regional and district centers and are inaccessible to rural residents. For example, in rural area of Ternopil region there are 23 ATCs and in only 3 of them there are CSSFCY and TCSS (Slozanska, 2017, p. 84-85).

In some areas there are practices of establishing Centres of Social Services (CSS), which are municipal institutions and provide a wide range of services which include 
paperwork for payment of pensions, subsidies and other state benefits provided by the system of social insurance, employment ans information services, etc. These institutions act as "one-stop-shops". However, such experience is an exception to the rule rather than an established practice. According to the Ministry of Regional Development, Construction and Housing and Communal Services of Ukraine, as of 01.02.2018, there were 108 public institutions providing social services in Ukraine (Kurilo \& Zanyuk, 2017). Practices when communities pay district and regional bodies and agencies for the provided services, rather than create their own structure still prevail (Popovych, 2018, p. 211).

Another mechanism for the administration of integrated social services at the ATC level involves pooling the resources of several communities to achieve goals that are difficult to achieve alone. The main forms of cooperation within the framework of intermunicipal cooperation are: delegation of social services with the transfer of appropriate resources to private, non-governmental, and other organizations; implementation of joint social projects; co-financing of municipal social services agencies; establishment of joint municipal enterprises for the provision of social services; creation of joint management bodies as separate executive bodies, for example, departments of social services, or establishment of new social work positions in the joint executive bodies responsible for social services provision (Kurilo \& Zanyuk, 2017).

Another example of services integration is the creation of mobile teams that provide social and psychological assistance to people affected by domestic and/or gender-based violence (Decree, 2018). Such structures are established at the CSSFCY or other specialized agencies, and must, as a minimum, consist of two professionals - a social worker and a psychologist. Today it is too early to judge the scope and effectiveness of the implementation of this legislative initiative, given its recent adoption.

The scientific literature substantiates the model of creating integrated social services. They are designed to support certain areas of social work aimed at providing targeted assistance to families and children in overcoming difficult life circumstances, based on an integrated approach (Svetlichnaya, 2009). Their structure may include: family support service, early intervention service, support service for family forms of child placement; service for reintegration and socialization of children in residential institutions etc. Other specialized services, such as support service for children with special educational needs can be introduced into the structure of integrated social service agencies based on the population needs and available in the community human and financial resources (Bezpalko et al. 2007, p. 82). Unfortunately, we could not find examples of the implementation of this model of integration in Ukraine.

The situation with the implementation of integrated social services is complicated by the fact that at the local level there is no long-term approach to solving social issues. The understanding the importance of programming, management and integration of services remains limited at best. The provision of social services is viewed in terms of costs, not in terms of social investment. Social services are not popular among clients of social agencies focused mainly on financial and in-kind assistance.

Many social services are institutionalized, especially the care of children deprived of parental care, the elderly and the disabled. Availability and quality of services depend mainly on the client's place of residence: traditionally, in cities they are better than in rural areas.

The introduction of outlined models of social services integration is complicated by the lack of qualified personnel, material and technical resources, and obsolescence of social infrastructure. The level of interaction and cooperation of different actors and institutions in responding to social problems of the population remains low, and the integration of social services is more innovative than systemic. 


\section{Conclusion}

The importance of implementation of integrated approach is due to the need to provide social assistance and support for all categories of vulnerable populations at their place of residence. In the most general form, the integration of social services provides for the introduction of a single system of planning and provision, which makes it possible to increase their accessibility, efficiency and effectiveness.

The results of the analysis of scientific literature demonstrated the existence of different approaches to the integration of social services and their combination. The most important conclusion that can be drawn from the analysis is that the integration approach makes it possible to implement one's own models of integrated services on the basis of preliminary assessment and planning. The success of integration initiatives depends on awareness and consistency of objectives, clear distribution of functions, introduction of financial and/or administrative incentives for cooperation, elimination of factors that would cause competition between service providers. The integration of services at the local level entails increased autonomy and new types of tasks, and this should be supported by capacity-building in planning, evaluation and management. A proposed agenda for further research includes the issues of interaction between partner organizations in the delivery of integrated services, the development of monitoring and evaluation capacities to improve integrated services provision.

\section{References}

Agranoff, R. (1991). Human services integration: Past and present challenges in public administration. Public Administration Review, 51(6), 533-542.

Austin, M. J., \& Prince, J. (2003). The implications of managed care and welfare reform for the integration of health and welfare services. Journal of Health and Social Policy, 18(2), 1-19.

Borghi, Vando, and Rik Van Berkel. (2007). New Modes of government in Italy and the Netherlands: The Case of Activation Policies. Public Administration 85 (1): 83-101.

Estes, R. (2000). J. (1997). Social work, social development and community welfare centers in international perspective. International Social Work, 40(1), 43-55.

Fisher, M. P., \& Elnitsky, C. (2012). Health and social services integration: a review of concepts and models. Social work in public health, 27(5), 441-468.

Hassett, S., \& Austin, M. J. (1997). Service integration: Something old and something new. Administration in Social Work, 21(3/4), 9-29.

Heidenreich, M. and Aurich, P. (2013). European worlds of employment and social services: The local dimension of activation policies, University of Oldenburg.

Hollerts, K. (2016) Integrated and individualized services: Paradoxes in the implementation of labour market policies in Sweden, In: Heidenreich, M. and Rice D. (eds.), Integrating Social and Employment Policies in Europe Active Inclusion and Challenges for Local Welfare government, Edward Elgar, Cheltenham, United Kingdom, 51-71.

Horishna, N. (2018). Quality as criteria of monitoring and evaluation of social services: opportunities or limits? Social Work and Education, Vol. 5, No. 4., pp. 84-103. [In Ukrainian].

Hutson, R. (2000). Q., \& CLASP. (2004). Providing Comprehensive, Integrated Social Services to Vulnerable Children and Families: There Are Legal Barriers at the Federal Level to Moving Forward?. Center for Law and Social Policy.

Ilchuk, L. I., \& Ylchuk, L. Y. (2018). Development of the system of integrated social services in the conditions of decentralization (on the example of the united territorial communities). Sotsialno-trudovi vidnosyny: teoriia ta praktyka, 2018. No. 1, pp. 116-123. [In Ukrainian]. 
Koval, O. P. (2014). Modernization of the social insurance system in Ukraine. Analitychna dopovid. K.: NISD. IIn Ukrainian].

Kurylo, O. B., \& Zaniuk, A. F. (2017). Monitoring the process of decentralization of power and reform of local self-government. [In Ukrainian].

Literature review and identification of best practices on integrated social service delivery (2015). doi:10.2767/35529

Minas, R. (2009). Activation in integrated sevices? Bridging social and employment services in European countries (No. 2009: 11). Institute for Futures Studies.

Munday, B. (2007). Integrated Social Services in Europe: Report. Council of Europe.

Popovych, A. (2018). Administration of Integrated Social Services at the Community Level. Naukovyi visnyk Uzhhorodskoho universytetu. Seriia:"Pedahohika. Sotsialna robota", (2 (43)), 210-213. [In Ukrainian].

Popyk, Yu. (2016). Organization of integrated social services in the territorial communities. Naukovvi visnyk Uzhhorodskoho universytetu. Seriia:"Pedahohika. Sotsialna robota, (2), 193-196. [In Ukrainian].

Resolution of the Cabinet of Ministers of Ukraine No. 654 dated August 22, 2018 "On Approval of the Model Regulations on the Mobile Brigade of Social-Psychological Assistance to Persons Affected by Domestic Violence and / or Violence on the basis of Sex". Retrieved from https:/www.kmu.gov.ua/ua/npas/pro-zatverdzhennya-tipovogopolozhennya-pro-mobilnu-brigadu-socialno-psihologichnoyi-dopomogi-osobam-yakipostrazhdali-vid-domashnogo-nasilstva-taabo-nasilstva-za-oznakoyu-stati. [In Russian].

Ryant, J. C. (1976). The integration of services in rural and urban communities. Canadian Journal of Social Work Education/Revue canadienne d'éducation en service social, 5-14.

Slozanska, H. (2017). Are future social workers of bachelor degree ready to provide integrated social services in the territorial community in Ukraine. Social Work and Education, Vol. 5, No. 4., pp. 84-103. [In Ukrainian].

Slozanska, H. (2017). Social services: are current state social agencies ready to provide them on the level of local communities in Ukraine (selective survey). Social Work and Education, Vol. 4, No. 2., pp. 77-101. [In Ukrainian].

Stevens, J. (2000). M., \& Webster, T. C. (1978). Human services integration: Toward clarification of a concept. Journal of Health and Human Resources Administration, 1(1), 109-126.

Svitlychna, T. V. (2009). The development of integrated social services as an innovative model for providing social services to the population. Derzhavne budivnytstvo, (1). [In Ukrainian].

Taylor, A. (2009). Good Practices in providing integrated employment and social services in Central and Eastern Europe. Draft Report to ILO Retrieved from http://rs.one.un.org/organizations/12/Integrated\%20service\%20delivery publication.pdf.

Thistlethwaite, P. (2008). Bringing the NHS and Local Government together. A practical guide to integrated working.

Van Breda, A. O. (2007). Implications of Developmental Social Welfare for Occupational Social Work. In ASASWEI Annual Conference, University of Johannesburg, Johannesburg, South Africa (pp. 3-4). - P. 3.

Wharf, B. (1977). Integrated services: myths and realities. Canadian Journal of Social Work Education/Revue canadienne d'éducation en service social, 24-31. - P. 26.

Wharf, B. (1977). Integrated services: myths and realities. Canadian Journal of Social Work Education/Revue canadienne d'éducation en service social, 24-31. - P. 26.

Wollmann, H., Koprić, I., \& Marcou, G. (Eds.). (2016). Public and social services in Europe: From public and municipal to private sector provision. Springer. 


\title{
СУТНІСТЬ ТА ОСОБЛИВОСТІ ВПРОВАДЖЕННЯ ІНТЕГРОВАНИХ СОЦІАЛЬНИХ ПОСЛУГ В УКРАЇНІ
}

\author{
Надія Горішна, кандидат педагогічних наук, дочент кафедри сочіальної \\ педагогіки і соиіальної роботи, Тернопільський національний педагогічний \\ університет імені Володимира Гнатюка, м. Тернопіль, Україна \\ nadiahorishna@yahoo.com
}

Анотація. Актуальність статті зумовлена необхідністю впровадження інтегрованих соиіальних послуг на місиевому рівні в умовах децентралізації влади та об'єднання територіальних громад. Важливість впровадження інтегрованого підходу зумовлена необхідністю надання сочіальної допомоги та підтримки усіх категорій населення, а особливо вразливих груп, за місием їх проживання.

Метою статті є аналіз існуючих підходів до інтеграчії сочіальних служб та визначення можливостей їх застосування в контексті децентралізації соиіальних послуг на місиевому рівні в Україні. Для досягнення мети було використано метод "кабінетного дослідження", заснований на аналізі даних соиіальних досліджень, аналітичних доповідей, публікачій та інших наукових матеріалів.

Результати аналізу наукової літератури продемонстрували наявність різних підходів до інтеграції соціальних служб. У найбільш загальному вигляді вона передбачає запровадження єдиної системи їх планування та надання, щуо дає змогу підвищити доступність, ефективність та результативність послуг. Впровадження інтегрованого підходу до надання сочіальних послуг на місцевому рівні вимагає попередньої очінки, планування та співпраці на основі визначення спільних иілей та завдань, чіткого розподілу функиій, запровадження фінансових та/або адміністративних стимулів до співпращі, усунення факторів, які б спричинили конкуренцію між постачальниками послуг, та розвиток їх спроможності у питаннях сочіального планування, оцінки та управління.

Впровадженню інтегрованих сочіальних послуг в Украӥні перешкоджають такі чинники, як: відсутність довгострокового підходу до вирішення соціальних проблем; нерозуміння важливості планування та програмного підходу до надання послуг; домінуванням на рівні керівничтва підходу, при якому надання сочіальних послуг розглядається з точки зору витрат, а не соціальних інвестицій; зорієнтованістю клієнтів сочіальних служб переважно на отримання фінансової та натуральної допомоги; інституціалізованістю соціальних служб.

Ключові слова: інтеграція; суспільні послуги; інтегровані сочіальні послуги; сочіальне забезпечення; об'єднані територіальні громади.

\section{References}

Agranoff, R. (1991). Human services integration: Past and present challenges in public administration. Public Administration Review, 51(6), 533-542.

Austin, M. J., \& Prince, J. (2003). The implications of managed care and welfare reform for the integration of health and welfare services. Journal of Health and Social Policy, 18(2), 1-19.

Borghi, Vando, and Rik Van Berkel. 2007. New Modes of Governance in Italy and the Netherlands: The Case of Activation Policies. Public Administration 85 (1): 83-101.

Estes, R. J. (1997). Social work, social development and community welfare centers in international perspective. International Social Work, 40(1), 43-55.

Fisher, M. P., \& Elnitsky, C. (2012). Health and social services integration: a review of concepts and models. Social work in public health, 27(5), 441-468. 
Hassett, S., \& Austin, M. J. (1997). Service integration: Something old and something new. Administration in Social Work, 21(3/4), 9-29.

Heidenreich, M. and Aurich, P. (2013). European worlds of employment and social services: The local dimension of activation policies, University of Oldenburg.

Hollerts, K. (2016) Integrated and individualized services: Paradoxes in the implementation of labour market policies in Sweden, In: Heidenreich, M. and Rice D. (eds.), Integrating Social and Employment Policies in Europe Active Inclusion and Challenges for Local Welfare Governance, Edward Elgar, Cheltenham, United Kingdom, 51-71.

Horishna, N. (2018). Якість як критерій моніторингу та оцінювання соціальних послуг: можливості чи обмеження ?, Social Work and Education, Vol. 5, No. 4., pp. 19-32.

Hutson, R. Q., \& CLASP. (2004). Providing Comprehensive, Integrated Social Services to Vulnerable Children and Families: Are There Legal Barriers at the Federal Level to Moving Forward?. Center for Law and Social Policy.

Literature review and identification of best practices on integrated social service delivery (2015). doi:10.2767/35529

Minas, R. (2009). Activation in integrated services ?. Bridging social and employment services in European countries (No. 2009: 11). Institute for Futures Studies.

Munday, B. (2007). Integrated Social Services in Europe: Report. Council of Europe.

Ryant, J. C. (1976). The integration of services in rural and urban communities. Canadian Journal of Social Work Education/Revue canadienne d'éducation en service social, 5-14.

Stevens, J. M., \& Webster, T. C. (1978). Human services integration: Toward clarification of a concept. Journal of Health and Human Resources Administration, 1(1), 109-126.

Taylor, A. (2009). Good Practices in providing integrated employment and social services in Central and Eastern Europe. Draft Report to ILO Retrieved from http://rs.one.un.org/organizations/12/Integrated\%20service\%20delivery_publication.pdf

Thistlethwaite, P. (2008). Bringing the NHS and Local Government together. A practical guide to integrated working.

Van Breda, A. D. (2007). Implications of Developmental Social Welfare for Occupational Social Work. In ASASWEI Annual Conference, University of Johannesburg, Johannesburg, South Africa (pp. 3-4).- C. 3.

Wharf, B. (1977). Integrated services: myths and realities. Canadian Journal of Social Work Education/Revue canadienne d'éducation en service social, 24-31. - C. 26.

Wollmann, H., Koprić, I., \& Marcou, G. (Eds.). (2016). Public and social services in Europe: From public and municipal to private sector provision. Springer.

Безпалько, О. В., Звєрєва, І. Д., Кияниця, 3. П., \& Кузьмінський, В. О. (2007). Інтегровані соціальні служби: теорія, практика, інновації:[навч.-метод. комплекс]. К.: Фенікс.

Горемикіна, Ю. В. (2009). Проблеми розвитку недержавних організацій у сфері надання соціальних послуг. Демографія та соиіальна економіка, (1), 161-168.

Ільчук, Л. І., \& Ильчук, Л. И. (2018). Розвиток системи інтегрованих соціальних послуг в умовах децентралізації (на прикладі об'єднаних територіальних громад). Соціально-трудові відносини: теорія та практика, 2018. № 1, C. 116-123.

Коваль, О. П. (2014). Модернізація системи соціального страхування в Україні. Аналіт. доп. К.: НІСД.

Курило, О. Б., \& Занюк, А. Ф. (2017). Моніторинг процесу децентралізації влади та реформування місцевого самоврядування. 
Попик, Ю. (2016). Організація діяльності інтегрованих соціальних служб в територіальних громадах. Науковий вісник Ужгородського начіонального університету. Серія: Педагогіка. Соиіальна робота, (2), 193-196.

Попович, А. (2018). Адміністрування інтегрованих соціальних послуг на рівні громади. Науковий вісник Ужгородського університету. Серія:«Педагогіка. Соиіальна робота», (2 (43)), 210-213.

Постанова Кабірнету Міністрів України № 654 від 22 серпня 2018 р. «Про затвердження Типового положення про мобільну бригаду соціально-психологічної допомоги особам, які постраждали від домашнього насильства та/або насильства за ознакою статі». Retrieved from https://www.kmu.gov.ua/ua/npas/pro-zatverdzhennyatipovogo-polozhennya-pro-mobilnu-brigadu-socialno-psihologichnoyi-dopomogiosobam-yaki-postrazhdali-vid-domashnogo-nasilstva-taabo-nasilstva-za-oznakoyu-stati

Світлична, Т. В. (2009). Розвиток інтегрованих соціальних служб як інноваційної моделі надання соціальних послуг населенню. Державне будівництво, (1).

Слозанська, Г. (2017). Чи здатні діючі державні соціальні агенції ефективно надавати соціальні послуги населенню на рівні отг: вибіркове дослідження. Social Work and Education, Vol. 4, No. 2., pp. 77-101.

Слозанська, Г. (2018). Чи готові майбутні соціальні працівники першого (бакалаврського) рівня вищої освіти до надання інтегрованих соціальних послуг у територіальній громаді? Social Work and Education, Vol. 5, No. 4., pp. 84-103. 